\title{
Ketahanan Korosi pada Paduan Mg -1Mn-HA Sebagai Bahan Biomaterial Hasil Proses Mechanosynthesis dalam Media Ringer Lachtate
}

\section{Corrosion Resistance in Mg-1Mn-Ha Alloy as Biomaterial from Mechanosynthesis Process in Ringer Lachtate Media}

\author{
Ihwan Bayu Setiawan ${ }^{1, *}$, Djoko Hadi Prajitno², R Henny Mulyani ${ }^{1}$ \\ ${ }^{1}$ Jurusan Teknik Metalurgi, Universitas Jenderal Achmad Yani, \\ Jalan Terusan Jenderal Gatot Subroto, Bandung 40285, Indonesia \\ ${ }^{2}$ PSTNT-BATAN, Jl. Tamansari No.71 Bandung 40132, Indonesia \\ *E-mail: ihwanbayu12@gmail.com
}

DOI: https://doi.org/10.26874/jkk.v4i1.71

Received: 13 Feb 2021, Revised: 30 May 2021, Accepted: 30 May 2021, Online: 31 May 2021

\begin{abstract}
Abstrak
Biomaterial dari bahan biodegradable akhir-akhir ini sedang dilakukan penelitian lebih lanjut untuk menggantikan biomaterial non biodegradable yang memiliki sifat toksisitas di dalam tubuh namun material biodegradable memiliki sifat kimia-fisika dan sifat mekaniknya belum menyerupai tulang asli maka dari itu butuh paduan yang tepat untuk biomaterial biodegradable. Magnesium memiliki sifat biodegradable, biocompatible, non toxic, dengan modulus elastisitas $42 \mathrm{GPa}$ yang relatif dekat dengan modulus elastisitas tulang ( 3 - $40 \mathrm{GPa}$ ). Metode yang digunakan dalam pembuatan biomaterial dari bahan biodegradable adalah pemaduan mekanik pada paduan $\mathrm{Mg}-1 \% \mathrm{Mn}$ - Hydroxyapatite menggunakan metode mechanosynthesis. Dengan waktu milling 2 jam dengan kecepatan $1000 \mathrm{rpm}$. Tekanan Kompaksi $10 \mathrm{MPa}$ serta waktu sintering 2 jam sehingga menyebabkan terbentuknya porositas yang dihasilkan dari metode ini diisi oleh hydroxyapatite (HA) bereaksi membentuk ikatan jaringan dengan tulang. Karakterisasi paduan $\mathrm{Mg}-1 \% \mathrm{Mn}-\mathrm{HA}$ dilakukan dengan menggunakan pengujian kekerasan micro vickers, metalografi, laju korosi, SEM - EDS, dan XRD. Nilai kekerasan dari paduan $\mathrm{Mg}-1 \mathrm{Mn}$, nilai rata - rata kekerasan pada paduan $\mathrm{Mg}-1 \mathrm{Mn}$ Non HA yaitu $34,87 \mathrm{HVN}, \mathrm{Mg}-1 \mathrm{Mn}-$ $10 \%$ HA yaitu 42,03 HVN, Mg - 1Mn - 15\% HA yaitu 43,19 HVN, dan Mg - 1Mn - 20\% HA yaitu 47,79 HA. Analisis XRD dapat diketahui bahwa fasa yang terbentuk pada paduan Mg-1\% Mn yaitu terbentuk paduan $\mathrm{Mg}+\alpha \mathrm{Mn}$, dan pada padauan $\mathrm{Mg}-1 \% \mathrm{Mn}$ yaitu terbentuk $\mathrm{Mg}+\alpha \mathrm{Mn}$ dan $\mathrm{Ca}_{10}\left(\mathrm{Po}_{4}\right)_{6}(\mathrm{OH})_{2}$. Nilai laju korosi pada paduan $\mathrm{Mg}-1 \mathrm{Mn}-$ Non HA memiliki laju korosi $1.035 \mathrm{e}^{3} \mathrm{mpy}$ sedangkan pada sampel paduan $\mathrm{Mg}-1 \mathrm{Mn}$ - 10\% HA memiliki laju korosi 487 mpy.
\end{abstract}

Kata Kunci : Biomaterial, Biodegradable, Mechanosynthesis, Hidroxyapatite. Larutan Ringer Lachtate

\section{Abstract}

Recently, further research is being carried out to replace non-biodegradable biomaterials that have toxicity properties in the body, but biodegradable materials have chemical-physical properties and mechanical properties that do not resemble real bone, therefore we need the right alloy for biodegradable biomaterials. Magnesium is biodegradable, biocompatible, non-toxic, with an elastic modulus of $42 \mathrm{GPa}$ which is relatively close to the modulus of bone elasticity ( 3 - $40 \mathrm{GPa})$. The method used in the manufacture of biomaterials from biodegradable materials is the mechanical integration of the Mg - 1\% Mn - Hydroxyapatite alloy using the mechanosynthesis method. With a milling time of 2 hours at a speed of $1000 \mathrm{rpm}$. Compaction pressure of $10 \mathrm{MPa}$ and sintering time of 2 hours, causing the formation of porosity resulting from this method filled with hydroxyapatite (HA) reacts to form tissue bonds with the bone. Characterization of Mg - 1\% Mn - HA alloy was carried out using micro Vickers 
hardness testing, metallography, corrosion rate, SEM-EDS, and XRD. The hardness value of the $M g$ $1 \mathrm{Mn}$ alloy, the average hardness value of the $\mathrm{Mg}-1 \mathrm{Mn} \mathrm{Non}-\mathrm{HA}$ alloy is $34.87 \mathrm{HVN}, \mathrm{Mg}-1 \mathrm{Mn}-10 \%$ HA is $42.03 \mathrm{HVN}, \mathrm{Mg}-1 \mathrm{Mn}-15 \% \mathrm{HA}$ is $43.19 \mathrm{HVN}$, and Mg - 1Mn - 20\% HA, namely $47.79 \mathrm{HA}$. XRD analysis shows that the phase formed in the $\mathrm{Mg}-1 \% \mathrm{Mn}$ alloy is formed by the $\mathrm{Mg}+\alpha \mathrm{Mn}$ alloy and in the Mg-1\% Mn mixture, which is formed $\mathrm{Mg}+\alpha \mathrm{Mn}$ and Cal0 (Po4) 6 (OH) 2. The corrosion rate value of the Mg - $1 \mathrm{Mn}$ - Non-HA alloy has a corrosion rate of 1.035 e3 mpy while the $\mathrm{Mg}-1 \mathrm{Mn}-10 \%$ HA alloy sample has a corrosion rate of 487 mpy.

Keywords: biomaterial, biodegradable, mechanosynthesis, hidroxyapatite, ringer lachtate solution

\section{Pendahuluan}

Biomaterial dari bahan biodegradable ini sedang dilakukan penelitian lebih lanjut untuk menggantikan biomaterial non biodegradable yang memiliki sifat toksisitas di dalam tubuh namun material biodagradable memiliki sifat kimia-fisika dan sifat mekaniknya belum menyerupai tulang asli maka dari itu butuh paduan yang tepat untuk biomaterial biodegradable [1].

Salah satu bahan material yang sedang dikembangkan di dunia medis saat ini adalah magnesium sebagai bahan biomaterial. Magnesium menunjukkan harapan besar sebagai bahan biokompatibel dan biodegradable yang potensial [2].

Paduan magnesium merupakan biomaterial biodegradable yang paling banyak digunakan dan sudah mempunyai standar internasional dalam pemakaiannya. Kelebihan daripada paduan magnesium sebagai biomaterial biodegradable adalah mempunyai sifat mekanik dan biokompatibilitas yang baik. Magnesium dan paduan magnesium juga mempunyai massa jenis yang rendah $\left(1,74-2.0 \mathrm{~g} / \mathrm{cm}^{3}\right)$ lebih rendah daripada paduan titanium $\left(4.4-4.5 \mathrm{~g} / \mathrm{cm}^{3}\right)$. Ketangguhan dari paduan magnesium juga lebih besar daripada biomaterial keramik dengan nilai modulus elastis (41-45 GPa) yang mendekati nilai modulus tulang [3].

Tujuan penelitian ini adalah untuk mengetahui pengaruh penambahan senyawa hydroxyapatite (HA) terhadap kekerasan dan struktur mikro pada paduan $\mathrm{Mg}-\mathrm{Mn}$, dan untuk mengetahui pengaruh penambahan senyawa hydroxyapatite (HA) terhadap laju korosi paduan $\mathrm{Mg}-\mathrm{Mn}-\mathrm{HA}$, dan untuk mengetahui apakah material yang digunakan bersifat biodegradable.

Melalui hasil penelitian ini dapat menambah pengetahuan bagi dunia medis untuk menggunakan logam magnesium yang dipadukan dengan mangan dan juga senyawa hydroxyapatite (HA) sebagai bahan alternatif pemasangan implan dengan cara lebih mudah dan murah.
Untuk mendapatkan paduan yang tepat dan memperbaiki sifat mekanik dari magnesium, maka dipadukan dengan mangan. Pengaruh penambahan mangan memiliki kekuatan tarik yang baik, keuletan yang baik, laju mulur yang baik, serta tingkat kehalusan butir yang halus. Namun penambahan unsur mangan yang melebihi ambang batas maka dapat menyebabkan neurotoxic dalam konsentrasi yang tinggi [4].

Hydroxyapatite (HA, $\left.\mathrm{Ca}_{10}\left(\mathrm{PO}_{4}\right)_{6}(\mathrm{OH})_{2}\right)$, merupakan komponen utama pada mineral dan bagian penting dari jaringan keras asli. HA banyak digunakan dalam bedah maksilosofasial, gigi, dan ortopedik untuk rekontruksi tulang dan gigi yang rusak karena sangat baik biokompatibilitas, bioaktivasi, dan sifat osteokonduktif yang baik [5].

Mechanosynthesis adalah metode mekanik secara langsung, yang didasarkan pada efek aktivasi mekanik yang dihasilkan dari bola baja yang saling bertabrakan selama proses penggilingan di dalam vial. Untuk proses penggilingan, beberapa parameter kontrol harus dipertimbangkan, yaitu lingkungan dalam vial, rasio berat bola ke bubuk dan agen kontrol proses [6].

\section{Metode Penelitian}

Bahan baku yang digunakan untuk pembuatan sampel serta dengan tingkat kemurniannya. serbuk magnesium $(\mathrm{Mg})$ merck dengan kemurnian 98\%, serbuk mangan (Mn) merck dengan kemurnian 98\%, serbuk HA dari tulang sapi yang dikeringkan dalam oven selama 120 menit di suhu $800^{\circ} \mathrm{C}$ lalu dihaluskan menggunakan planetary ball mill selama 120 menit dengan kecepatan 100rpm.

Komposisi kimia paduan $\mathrm{Mg}-1 \mathrm{Mn}$ dan hydroxyapatite dihitung dengan menggunakan metode persen berat. Seperti yang ditunjukkan pada Tabel 1. 
Tabel 1. Kodefikasi Spesimen Uji dalam \%Berat

\begin{tabular}{cccc}
\hline Sampel Uji & \multicolumn{3}{c}{ \% Berat (g) } \\
\cline { 2 - 4 } & Mg & Mn & HA \\
\hline$M g-1 M n-$ Non-HA & 6,93 & 0,07 & - \\
$M g-1 M n-10 \%$ HA & 6,23 & 0,07 & 0,70 \\
$M g-1 M n-15 \%$ HA & 5,88 & 0,07 & 1,05 \\
$M g-1 M n-20 \%$ HA & 5,53 & 0,07 & 1,40 \\
\hline
\end{tabular}

Bahan yang digunakan dalam penelitian adalah serbuk magnesium, $1 \%$ mangan dan hydroxyapatite (HA) yang dilakukan proses milling dengan ratio ball mill 10:1. Milling dilakukan selama 2 jam dengan kecepatan 1000 rpm. Material yang sudah homogen dilakukan proses kompaksi dengan tekanan $100 \mathrm{~kg} / \mathrm{mm}^{2}$ membentuk pelet dengan diameter $16 \mathrm{~mm}$. Sintering dilakukan pada suhu $550^{\circ} \mathrm{C}$ selama 2 jam pada tube furnace dengan dialiri gas argon. Sampel hasil sintering didinginkan secara perlahan di dalam tungku. Pengujian yang dilakukan yaitu XRD, Hardness Vickers, metalografi, korosi polarisasi tafel, dan SEMEDS.

Pengujian kekerasan yang dilakukan pada spesimen Mg-1Mn-Non HA, Mg-1Mn-10\%HA, Mg-1Mn-15\% HA, dan Mg-1Mn-20\%HA hasil proses sintering menggunakan metode microVickers dengan berat pembebanan sebesar 500 gram dan dengan waktu penekanan 10 detik. Setiap spesimen dilakukan pengujian kekerasan pada 5 titik yang berbeda.

Preparasi permukaan paduan $\mathrm{Mg}-1 \mathrm{Mn}$ yang ditambahkan hydroxyapatite sebelum dilakukan karakterisasi dengan cara melakukan proses pengampelasan dengan nilai kekasaran yang berbeda dimulai dari 80 mesh hingga 2000 mesh . Pengujian metalografi dilakukan dengan menggunakan larutan etsa nital 5\% lalu dilakukan pengamatan struktur mikro menggunakan Optical Microscope (OM) Olympus BX60M.

Pengujian korosi dilakukan pada spesimen Mg-1Mn-Non HA, dan Mg - 1Mn - 10\% hasil proses sintering menggunakan metode polarisasi ASTM G59 dengan bantuan plat $\mathrm{Pt}$ dan $\mathrm{Ag}-\mathrm{AgCl}$ sebagai counter electrode dan reference electrode dalam media larutan SBF $+\mathrm{NaF}$ dan minuman berkarbonasi dengan waktu perendaman 10 menit. Data pengujian korosi didapat dengan menggunakan software Gamry Instrument Framework dan Gamry Echem Analyst.

\section{$3 \quad$ Hasil dan Diskusi}

3.1 Morfologi Permukaan Secara Makro

Gambar 1 memperlihatkan foto morfologi makro permukaan spesimen secara visual dengan menggunakan kamera digital. Pengamatan foto makro bertujuan untuk mengetahui gambaran permukaan dari paduan $\mathrm{Mg}-\mathrm{Mn}$ dengan persentase penambahan (\%) hydroxyapatite setelah proses sintering.

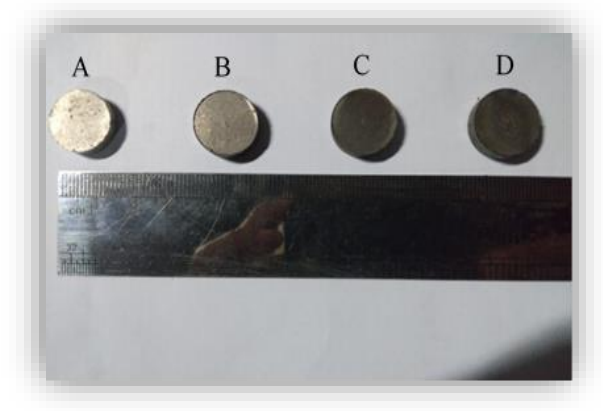

Gambar 1. Morfologi Permukaan Sebelum Proses Karakterisasi (a) Spesimen I (Mg-1MnNon-HA), (b) Spesimen II (Mg-1Mn-10\%HA), (c) Spesimen III (Mg-1Mn-25\%HA), dan (c) Spesimen IV (Mg-1Mn-20\%HA).

\subsection{Pemeriksaan Metalografi}

Pengujian struktur mikro dilakukan menggunakan mikroskop optik dengan metode metalografi. Pengujian metalografi dilakukan bertujuan untuk mengetahui perbedaan struktur mikro pada material paduan $\mathrm{Mg}-\mathrm{Mn}$ dan persentase hydroxyapatite hasil proses proses dari sintering. Hasil dari pemeriksaan struktur mikro dapat dilihat pada Gambar 2.

Hasil dari pemeriksaan struktur mikro dengan metode metalografi kualitatif dengan pembesaran $500 \mu \mathrm{m}$ menunjukkan bahwa, beberapa daerah yang berbeda dengan indikasi warna putih besar yaitu magnesium, dan warna putih pudar yang tersebar merata yaitu hydroxyapatite yang terlihat pada Gambar 3 dengan campuran senyawa hydroxyapatite, warna hitam kecil yaitu $\alpha$ mangan. Warna hitam pekat dan terlihat memiliki kedalaman yang berbeda yaitu porositas yang terbentuk pada paduan tersebut. 
Data hasil pemeriksaan struktur mikro kuantitatif dilakukan degan menghitung diameter ukuran butir menggunakan metode jeffreis dengan foto struktur mikro perbesaran $500 \mu \mathrm{m}$ dilihat pada Gambar 3.

Data hasil pemeriksaan struktur mikro kuantitatif dilakukan degan menghitung diameter ukuran butir menggunakan metode jeffreis maka didapatkan besar butir yang berbeda - beda, semakin banyak penambahan senyawa

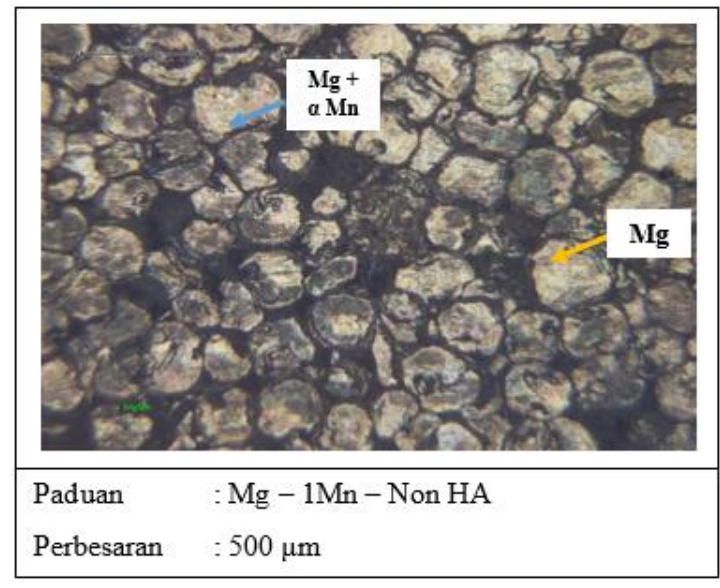

(a) Mg-1Mn-Non HA

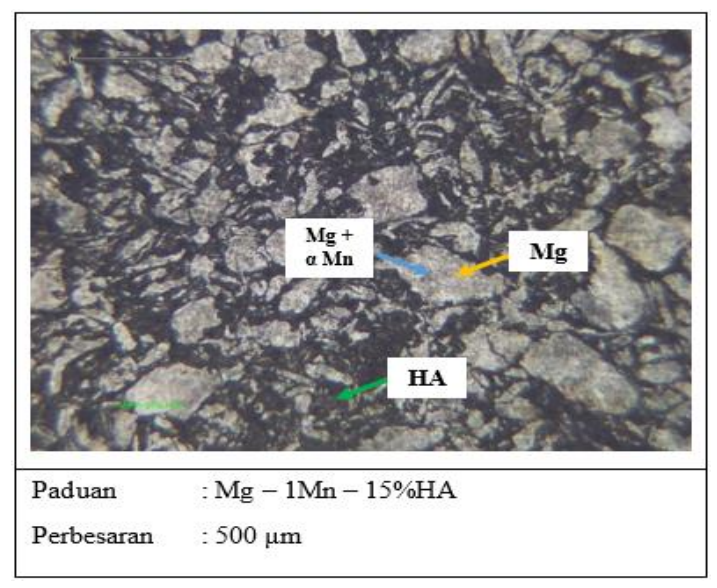

(c) $\mathrm{Mg}-1 \mathrm{Mn}-15 \% \mathrm{HA}$ hydroxyapatite maka besar diameter butir pun akan mengecil dan banyak.

Dapat dilihat pada Gambar 5 didapatkan diameter besar butir yang berbeda, pada paduan $\mathrm{Mg}-1 \mathrm{Mn}$ Non-HA didapatkan besar diameter butir sebesar 210,6 $\mu \mathrm{m}$, paduan $\mathrm{Mg}-1 \mathrm{Mn}-10 \%$ HA didapatkan besar diameter butir sebesar 179,3 $\mu \mathrm{m}$, paduan $\mathrm{Mg}-1 \mathrm{Mn}-15 \% \mathrm{HA}$ didapatkan besar diameter butir sebesar $147,79 \mu \mathrm{m}$, dan paduan $\mathrm{Mg}-1 \mathrm{Mn}-20 \% \mathrm{HA}$ didapatkan besar diameter butir sebesar $120,80 \mu \mathrm{m}$.

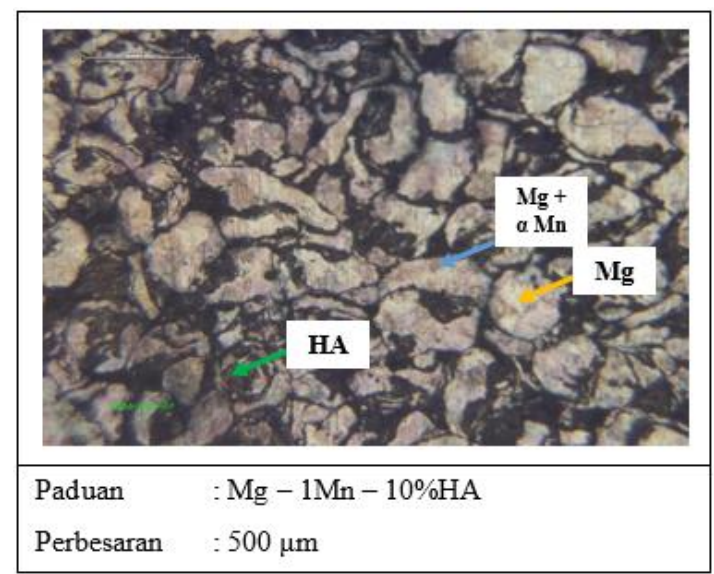

(b). Mg-1Mn-10\% HA

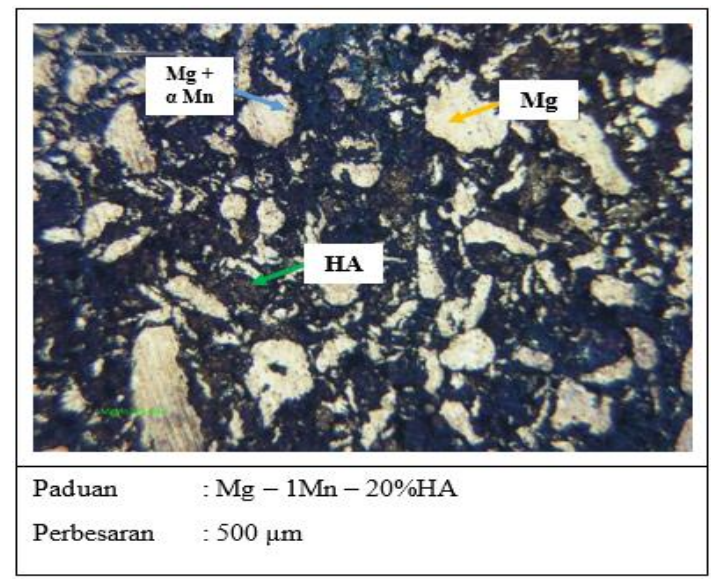

(d) $\mathrm{Mg}-1 \mathrm{Mn}-20 \% \mathrm{HA}$

Gambar 2. Hasil Pemeriksaan Metalografi dengan Perbesaran 500 $\mu$ m. 


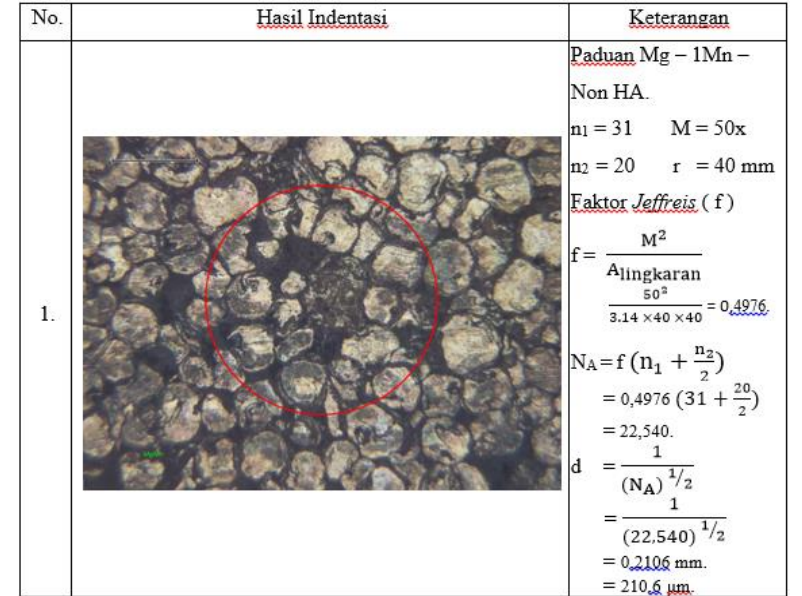

(a) Mg-1Mn-Non HA

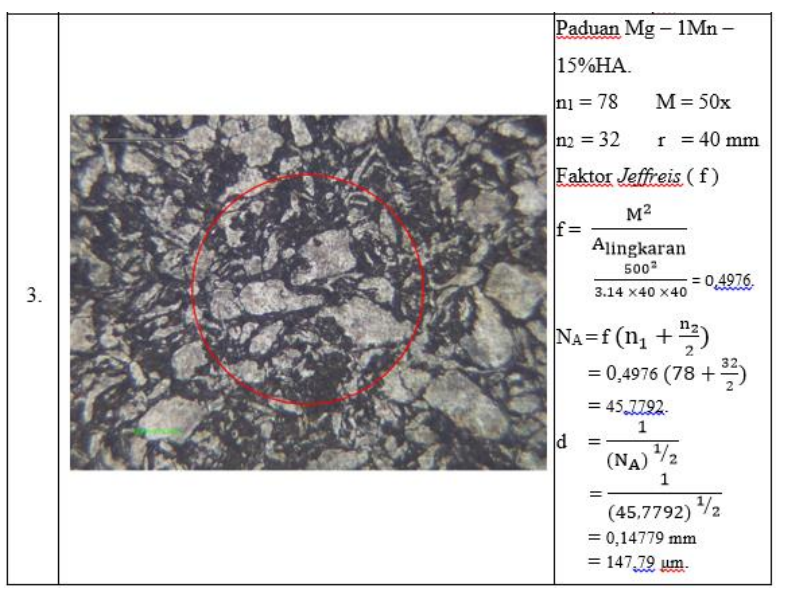

(c) $\mathrm{Mg}-1 \mathrm{Mn}-15 \% \mathrm{HA}$

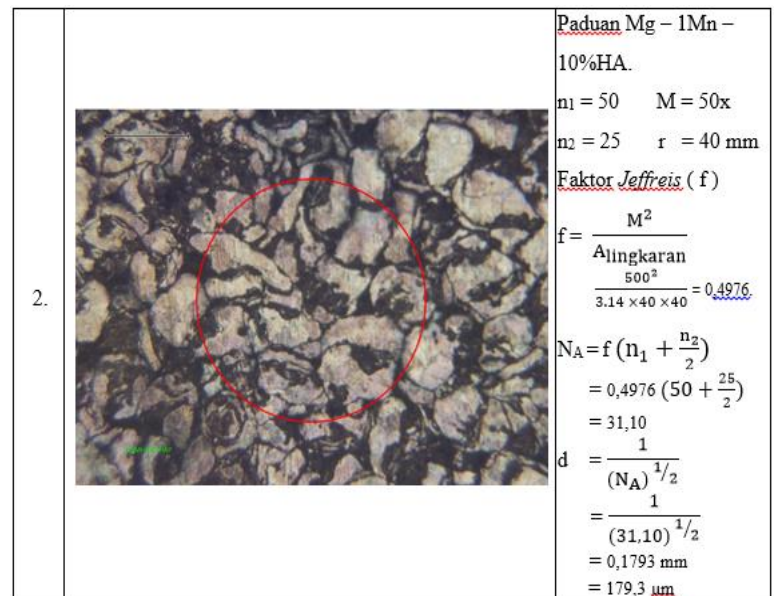

(b) $\mathrm{Mg}-1 \mathrm{Mn}-10 \% \mathrm{HA}$

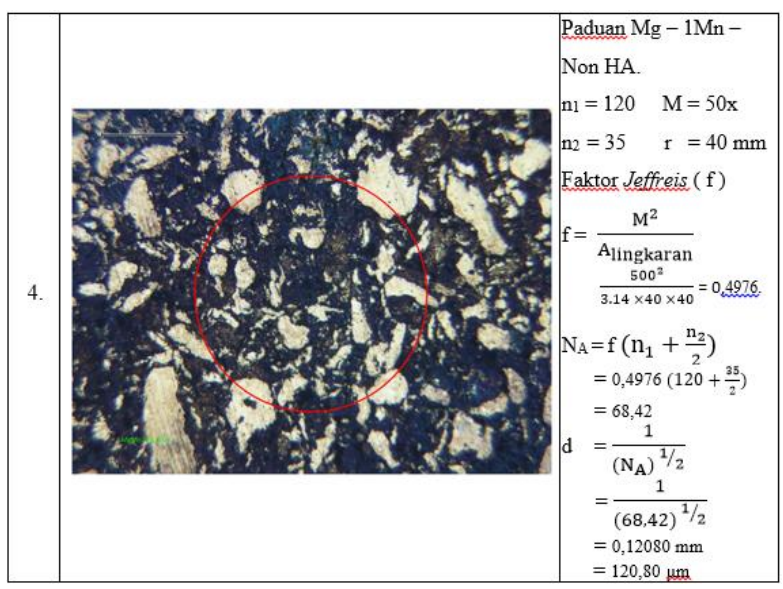

(d) $\mathrm{Mg}-1 \mathrm{Mn}-20 \% \mathrm{HA}$

Gambar 3. Hasil Pemeriksaan Struktur Mikro Kuantitatif Menggunakan Metode Jeffreis.

Data hasil pemeriksaan struktur mikro kuantitatif dilakukan degan menghitung diameter ukuran butir menggunakan metode jeffreis maka didapatkan besar butir yang berbeda - beda, semakin banyak penambahan senyawa hydroxyapatite maka besar diameter butir pun akan mengecil dan banyak.

Dapat dilihat pada Gambar 4 didapatkan diameter besar butir yang berbeda, pada paduan $\mathrm{Mg}-1 \mathrm{Mn}$ Non HA didapatkan besar diameter butir sebesar 210,6 $\mu \mathrm{m}$, paduan $\mathrm{Mg}-1 \mathrm{Mn}-10 \%$ HA didapatkan besar diameter butir sebesar 179,3 $\mu \mathrm{m}$, paduan $\mathrm{Mg}-1 \mathrm{Mn}-15 \%$ HA didapatkan besar diameter butir sebesar 147,79 $\mu \mathrm{m}$, dan paduan $\mathrm{Mg}-1 \mathrm{Mn}-20 \% \mathrm{HA}$ didapatkan besar diameter butir sebesar $120,80 \mu \mathrm{m}$.

\subsection{Pengujian Kekerasan}

Pengujian kekerasan dilakukan pada spesimen Mg-1Mn-Non HA, Mg-1Mn-10\% HA, Mg-1Mn-15\% HA, dan Mg-1Mn-20\% HA. Dari lima titik pengujian yang dilakukan pada setiap spesimen dihasilkan nilai rata-rata kekerasan kemudian dibandingkan antar spesimen uji.

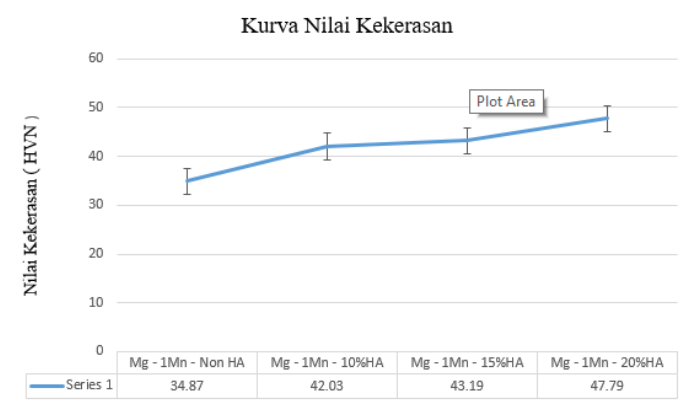

Gambar 4. Grafik Hasil Pengujian Kekerasan. 
Dari data pada Gambar 4 menunjukan bahwa dengan adanya penambahan persentase dari senyawa hydroxyapatite maka meningkat pula nilai kekerasannya hal ini diakibatkan dengan adanya penambahan hydroxyapatite menyebabkan sampel menjadi padat. Untuk nilai

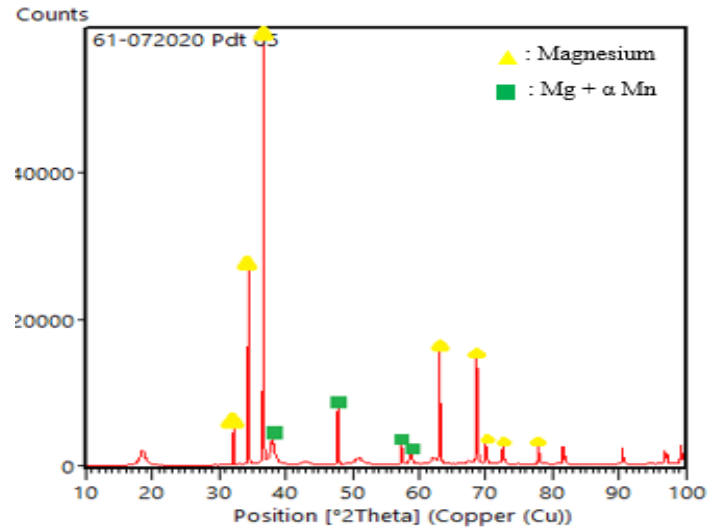

(a) Mg-1Mn-Non HA kekerasan dari masing-masing paduan dan waktu sintering yang sama tersebut maka didapatkan nilai rata-rata kekerasan pada paduan $\mathrm{Mg}-1 \mathrm{Mn}$ Non HA yaitu 34,7 HVN, Mg-1 Mn-10\% HA yaitu 42,03 HVN, Mg-1Mn-15\%HA yaitu 43,19 HVN, dan Mg-1Mn-20\%HA yaitu 47,79 HVN.

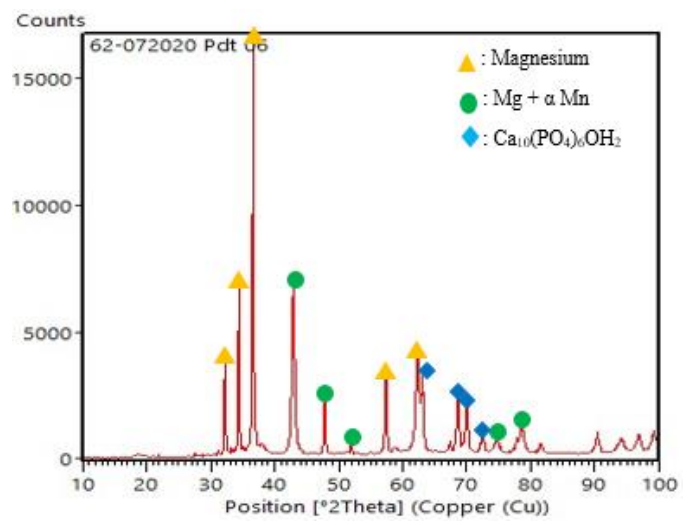

(b) $\mathrm{Mg}-1 \mathrm{Mn}-20 \% \mathrm{HA}$

Gambar 5. Hasil pengujian XRD Hasil Proses Sintering.

\subsection{Pengujian XRD}

Pengujian X-Ray Diffraction (XRD) dilakukan untuk mengetahui fasa atau senyawa yang terdapat pada paduan $\mathrm{Mg}-1 \mathrm{Mn}$ Non Hydroxyapatite dan Mg-1Mn-20\%HA. Pengujian $X$-Ray Diffraction dilakukan di PSTNT BATAN Bandung. Hasil dari pengujian X-Ray diffraction (XRD) ditunjukkan pada grafik Gambar 6a dan 6b. Pada analisis XRD dapat diketahui bahwa fasa yang terbentuk pada paduan $\mathrm{Mg}-1 \% \mathrm{Mn}$ dari Gambar 5 hasil XRD hanya terbentuk paduan $\mathrm{Mg}$ $+\alpha \mathrm{Mn}$ jumlah Mn yang hanya $1 \%$ tidak berikatan dengan $\mathrm{Mg}$, sedangkan pada spesimen $\mathrm{Mg}-1 \mathrm{Mn}$ 20\%-HA terbentuk paduan $\mathrm{Mg}+\alpha \mathrm{Mn}$ karena adanya penambahan dengan 20\% HA maka terbentuk $\mathrm{Ca}_{10}\left(\mathrm{Po}_{4}\right)_{6}(\mathrm{OH})_{2}$ atau HA, HA bersifat inert tidak bereaksi dengan logam maka tidak berikatan dengan paduan $\mathrm{Mg}$ dan $\alpha \mathrm{Mn}$.

\subsection{Pengujian SEM-EDS}

Pengujian SEM dilakukan untuk melihat morfologi permukaan sampel yang kita uji sedangkan EDS dilakukan untuk melihat persentase unsur pada titik tertentu pada sampel tersebut.

Berdasarkan data hasil pengujian SEM-EDS yaitu sampel paduan $\mathrm{Mg}-1 \mathrm{Mn}-\mathrm{Non} \mathrm{HA}$ dan $\mathrm{Mg}-$ $1 \mathrm{Mn}-20 \% \mathrm{HA}$ dengan perbesaran 10.000x (Gambar 6). Hasil dari pengujian SEM-EDS terlihat bahwa dengan penambahan hydroxyapatite menutupi rongga atau poros yang terbentuk pada sampel paduan $\mathrm{Mg}-1 \mathrm{Mn}$.

Pengujian EDS dilakukan pada full area dari sampel paduan $\mathrm{Mg}-1 \mathrm{Mn}$ yang ditambahkan hydroxyapatite. Dari hasil pengujian EDS (Tabel 2 dan 3) didapatkan komposisi dari sampel paduan $\mathrm{Mg}-1 \mathrm{Mn}$ - Non Hydroxyapatite terdapat unsur $\mathrm{O}$ atau oxygen hal ini terjadi karena magnesium sangat mudah bereaksi dengan oxygen hal ini dapat terjadi karena pada saat setiap prosesnya tidak dilakukan dengan cepat sehingga sampel bereaksi dengan $\mathrm{O}$, sedangkan pada paduan $\mathrm{Mg}$ $1 \mathrm{Mn}$ yang ditambahkkan dengan hydroxyapatite didapatkan bahwa dalam paduan $\mathrm{Mg}$ - $1 \mathrm{Mn}$ yang ditambahkan hydroxyapatite terdapat unsur Si dan juga $C$ yang cukup banyak, hal ini dikarena kan pada proses preparasi pada sampel kurang baik sehingga unsur $\mathrm{Si}$ dan $\mathrm{C}$ menyelip pada paduan $\mathrm{Mg}-1 \mathrm{Mn}$ hasil proses mechanosynthesis.

Untuk menghasilkan sampel paduan yang baik dan tidak mudah bereaksi dengan lingkungan sekitar, maka lebih baik menggunakan metode proses SPS (Spark Plasma Sintering), dengan menggunakan proses SPS dapat meminimalisir gradien thermal sehingga memungkinkan peningkatan laju pemanasan pada homogenitas yang dioptimalkan secara bersamaan. 


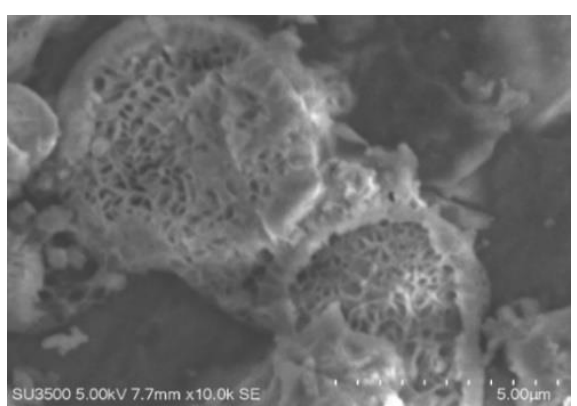

(a) Morfologi Sampel Paduan Mg-1Mn-NonHA

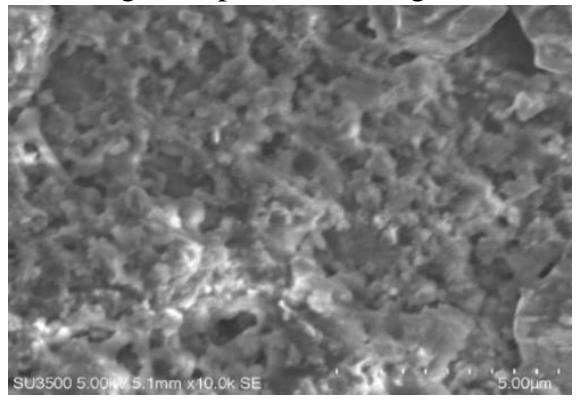

(b) Morfologi Sampel Paduan Mg-1Mn-20\%HA

Gambar 6. Hasil Pengujian SEM-EDS dengan Perbesaran 10.000x.

Tabel 2. Hasil EDS Sampel Mg-1Mn-NonHA

\begin{tabular}{cccc}
\hline Unsur & \%berat & \%Atom & \%Error \\
\hline $\mathrm{Mg}$ & 40,46 & 28,37 & 3,52 \\
$\mathrm{Mn}$ & 0,48 & 0,16 & 64,05 \\
$\mathrm{O}$ & 33,91 & 37,87 & 6,37 \\
$\mathrm{C}$ & 19,07 & 28,37 & 9,62 \\
\hline
\end{tabular}

\begin{tabular}{cccc}
\hline $\mathrm{Si}$ & 6,67 & 3,93 & 5,16 \\
\hline
\end{tabular}

Tabel 3. Hasil EDS Sampel Mg-1Mn-20\%HA

\begin{tabular}{cccc}
\hline Unsur & \%berat & \% atom & \% error \\
\hline $\mathrm{Mg}$ & 57,42 & 49,74 & 3,56 \\
$\mathrm{Mn}$ & 0,57 & 0,22 & 64,69 \\
$\mathrm{O}$ & 34,72 & 45,70 & 5,91 \\
$\mathrm{P}$ & 0,24 & 0,16 & 60,34 \\
$\mathrm{Ca}$ & 4,92 & 2,58 & 12,59 \\
$\mathrm{Si}$ & 2,13 & 1,60 & 8,66 \\
\hline
\end{tabular}

\subsection{Pengujian Korosi}

Pengujian korosi dilakukan untuk mengetahui perilaku korosi pada paduan $\mathrm{Mg}-$ $1 \mathrm{Mn}$ yang ditambahkan dengan persentase hydroxyapatite. Metode yang dilakukan pada pengujian korosi ini adalah ASTM G5-94 dalam larutan Simulated Fluid Ringer Laktat (SBF) dengan bantuan software Garmy Instrument untuk memantau laju korosi yang terjadi.

Data hasil kurva polarisasi Tafel (Gambar 7 dan 8) kemudian diplotkan dalam Tabel 4 untuk memudahkan perbandingan. Tabel 4 menunjukkan pengaruh penambahan senyawa hydroxyapatite serta waktu perendaman terhadap perilaku korosi paduan $\mathrm{Mg}-1 \mathrm{Mn}$ - Non $\mathrm{HA}, \mathrm{Mg}$ $-1 \mathrm{Mn}-10 \% \mathrm{HA}, \mathrm{Mg}-1 \mathrm{Mn}-15 \% \mathrm{HA}$, dan $\mathrm{Mg}$ - 1Mn - 20\%HA dalam media Simulated Body Fluid Ringer Laktat.

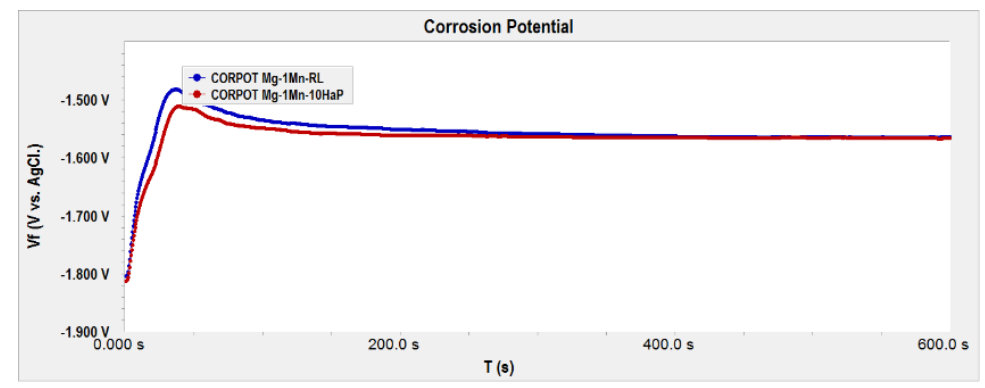

Gambar 7. Kurva potensial paduan Mg-1Mn-NonHA dan Mg-1Mn-10\%HA

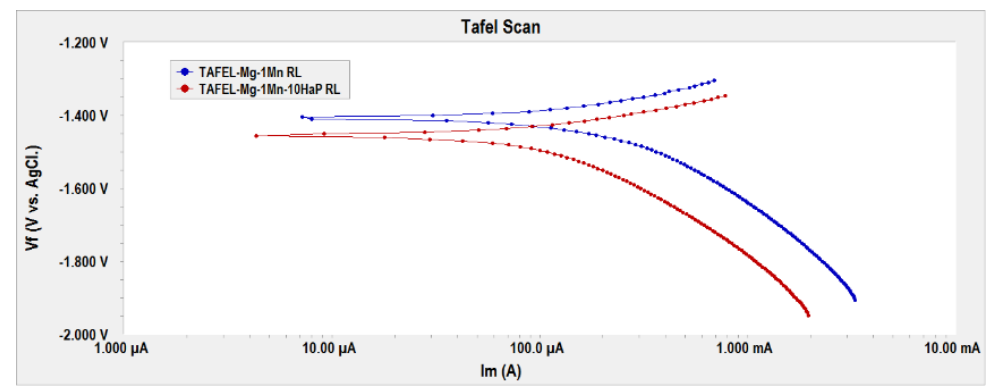

Gambar 8. Kurva tafel paduan Mg-1Mn-NonHA dan Mg-1Mn-10\%HA. 
Tabel 4. Data Pengujian Korosi

\begin{tabular}{ccc}
\hline $\begin{array}{c}\text { Sampel } \\
\text { Paduan }\end{array}$ & Keterangan & $\begin{array}{c}\text { Waktu } \\
\text { Perendaman } \\
\text { 10 menit }\end{array}$ \\
\hline & $\beta \mathrm{a}$ (V/decade) & $189,2 \mathrm{e}^{-3}$ \\
$\mathrm{Mg}-$ & $\beta \mathrm{c}(\mathrm{V} / \mathrm{dec}$ dede) & $358,6 \mathrm{e}^{-3}$ \\
$1 \mathrm{Mn}-$ & $\mathrm{I}_{\text {corr }}(\mu \mathrm{A})$ & 234,0 \\
$\mathrm{Non} \mathrm{HA}$ & $\mathrm{E}_{\text {corr }}(\mathrm{mV})$ & $-1,410$ \\
& Corrosion Rate & $1,035 \mathrm{e} 3$ \\
\hline & $($ mpy) & $120,8 \mathrm{e}^{-3}$ \\
$\mathrm{Mg}-$ & $\beta \mathrm{a}(\mathrm{V} / \mathrm{decade})$ & $348,6 \mathrm{e}^{-3}$ \\
$1 \mathrm{Mn}-$ & $\mathrm{I}_{\text {corr }}(\mu \mathrm{A})$ & 118,0 \\
$10 \% \mathrm{HA}$ & $\mathrm{E}_{\text {corr }}(\mathrm{mV})$ & $-1,450$ \\
& Corrosion Rate & 487,0 \\
\hline & (mpy) &
\end{tabular}

Dari data tersebut menunjukkan bahwa laju korosi pada paduan $\mathrm{Mg}-1 \mathrm{Mn}-$ Non HA memiliki laju korosi $1.035 \mathrm{e}^{3}$ mpy sedangkan pada sampel paduan $\mathrm{Mg}-1 \mathrm{Mn}-10 \%$ HA memiliki laju korosi 487 mpy.

Pada data hasil pengujian korosi dapat dilihat bahwa nilai korosi yang ditambahkan hydroxyapatite mengalami penurunan laju korosinya (Gambar 9). Hal ini disebabkan bahwa senyawa hydroxyapatite ini mengisi rongga yang telah terbentuk pada paduan $\mathrm{Mg}-1 \mathrm{Mn}$ sehingga rongga semakin kecil dan juga semakin padat. Semakin banyak panambahan hydroxyapatite maka rongga akan semakin banyak tertutupi sehingga nilai laju korosinya menjadi rendah.

\section{Kesimpulan}

Dengan penambahan hydroxyapatite (HA) mempengaruhi kekerasan dari paduan $\mathrm{Mg}-1 \mathrm{Mn}$, nilai rata - rata kekerasan pada setiap paduan mengalami peningkatan, selain itu pengaruh dari penambahan hydroxyapatite yaitu dapat memperhalus butir dan memperbanyak butir. Pengujian metalografi paduan $\mathrm{Mg}-1 \mathrm{Mn}$ pada diagram fasa biner $\mathrm{Mg}-\mathrm{Mn}$ pada suhu $50^{\circ} \mathrm{C}$ terbentuk fasa $\mathrm{Mg}+\alpha \mathrm{Mn}$ dan senyawa hydroxyapatite (HA) bersifat inert dan tidak bereaksi dengan logam paduan.

Hasil pengujian XRD ikatan yang terbentuk adalah $\mathrm{Mg}+\alpha \mathrm{Mn}$, sedangkan senyawa hydroxyapatite (HA) tidak bereaksi dengan material $\mathrm{Mg}-\mathrm{Mn}$ dan berdiri sendiri, pada grafik XRD unsur yang paling dominan adalah Mg. Hasil pengujian SEM - EDS dengan perbesaran

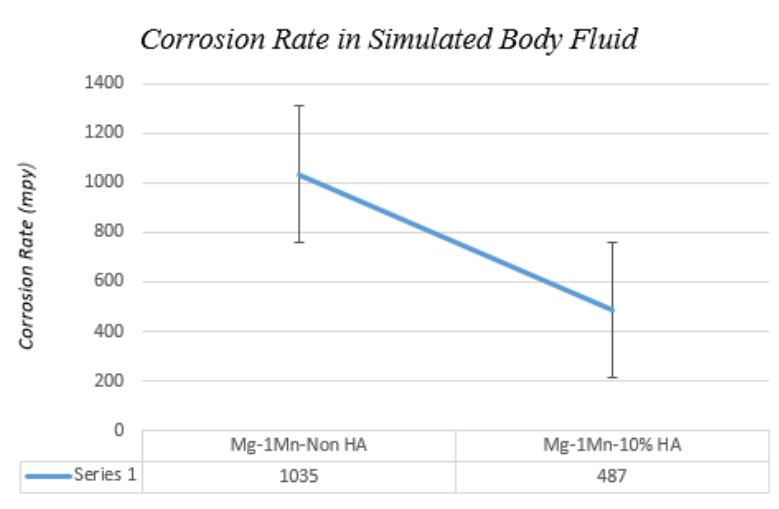

Gambar 9. Kurva Hasil Uji Polarisasi Dalam Larutan Simulated Body Fluid

10.000x dapat dilihat perbedaannya, yaitu paduan logam yang tidak ditambahkan hydroxyapatite (HA) memiliki rongga yang lebih besar, sedangkan pada paduan logam yang ditambahkan hydroxyapatite (HA) rongga terlihat sedikit. Hasil pengujian polarisasi didapat nilai laju korosi yang berbeda yaitu pada paduan $\mathrm{Mg}-1 \mathrm{Mn}$ - Non HA didapat nilai laju korosi $1.035 \mathrm{e}^{3} \mathrm{mpy}$, sedangkan pada paduan $\mathrm{Mg}-1 \mathrm{Mn}-10 \%$ HA didapatkan nilai laju korosi $487 \mathrm{mpy}$.

\section{Ucapan Terima Kasih}

Terima kasih kepada PSTNT BATAN Bandung yang telah memberikan bahan maupun fasilitas dalam penelitian ini.

\section{Daftar Pustaka}

[1]. Witte F, Hort N, Vogt C, Cohen S, Kainer $\mathrm{KU}$, Willumeit $\mathrm{R}$, et al. Degradable biomaterials based on magnesium corrosion. Curr Opin Solid State Mater Sci [Internet]. 2008;12(5-6):63-72. Available from: http://dx.doi.org/10.1016/j.cossms.2009.04.0 01

[2]. Brar HS, Platt MO, Sarntinoranont M, Martin PI, Manuel M V. Magnesium as a biodegradable and bioabsorbable material for medical implants. JOM. 2009;61(9):31-4. Available from: http://dx.doi.org/10.1007/s11837-009-01290

[3]. Lala S, Maity TN, Singha M, Biswas K, Pradhan SK. Effect of doping (Mg, Mn, Zn) on the microstructure and mechanical properties of spark plasma sintered 
hydroxyapatites synthesized by mechanical alloying. Ceram Int. 2017;43(2):2389-97. Available from: http://dx.doi.org/10.1016/j.ceramint.2016.11 .027

[4]. Salvetr P, Novák P, Vojtech D. Porous magnesium alloys prepared by powder metallurgy. Mater Tehnol. 2016;50(6):91722. Available from: http://dx.doi.org/10.17222/mit.2015.226

[5]. Itoh S, Kikuchi M, Koyama Y, Takakuda K, Shinomiya K, Tanaka J. Development of an artificial vertebral body using a novel biomaterial, hydroxyapatite/collagen composite. Biomaterials. 2002;23(19):391926. Available from: http://dx.doi.org/10.1016/s0142-
9612(02)00126-6

[6]. Nordin JA, Prajitno DH, Saidin S, Nur H, Hermawan H. Structure-property relationships of iron-hydroxyapatite ceramic matrix nanocomposite fabricated using mechanosynthesis method. Mater Sci Eng C. 2015;51:294-9. Available from: http://dx.doi.org/10.1016/j.msec.2015.03.01 9 